Etnográfica

Revista do Centro em Rede de Investigação em

Antropologia

vol. 21 (1) | 2017

Vol. 21 (1)

\title{
Religious dances and tourism: perceptions of the "tribal" as the repository of the traditional in Goa, India
}

Danças religiosas e turismo: os "tribais" percecionados como o repositório do tradicional em Goa, Índia

\section{Cláudia Pereira}

\section{(2) OpenEdition}

\section{Journals}

Electronic version

URL: https://journals.openedition.org/etnografica/4850

DOI: 10.4000/etnografica.4850

ISSN: 2182-2891

\section{Publisher}

Centro em Rede de Investigação em Antropologia

\section{Printed version}

Date of publication: 1 February 2017

Number of pages: 125-152

ISSN: 0873-6561

\section{Electronic reference}

Cláudia Pereira, "Religious dances and tourism: perceptions of the "tribal" as the repository of the traditional in Goa, India", Etnográfica [Online], vol. 21 (1) | 2017, Online since 11 March 2017, connection on 10 February 2022. URL: http://journals.openedition.org/etnografica/4850 ; DOI: https://doi.org/ 10.4000/etnografica.4850

\section{(c) (†) 8}

Etnográfica is licensed under a Creative Commons Attribution-NonCommercial 4.0 International License. 


\section{Religious dances and tourism: perceptions of the "tribal" as the repository of the traditional in Goa, India}

\section{Cláudia Pereira}

What changes occur in the identity of a group considered tribal in India through the performance of their dances? What is the influence of tourism on their religious cults? How are they perceived by other Indians? To answer these questions, first I analyze how the Goan government sought to institutionalize these tribal dances. Second, I examine the gains in the group's political, economic and cultural capital through this transition to the tourism industry. The article is based on long ethnographic research in Goa and the topic of folk musical heritage is approached from the perspective of anthropology. Its goal is to shed light on the relatively unknown musical heritage of the Catholic Gawda, also known as Kunnbi. It proposes that through tourism the Gawda, while still tribal, have become appreciated as a repository of traditional Goa, rather than pejoratively considered primitive (associated with backwardness) as they were regarded before, for keeping their village lifestyle. However, once the Catholic Gawda gained visibility vis-a-vis tourists and Goans themselves, thus becoming modern and global, they became paradoxically regarded as the continuers of ancestral practices. There is therefore a process of "invention of tradition," not so much as in the sense of creating what is revealed to tourists (although there is a standardization for the public), but rather in the interpretation of the Gawda who now represent an authentic Goan identity in their dancing.

KEYWORDS: folklorisation, tourism, ritual, invention of tradition, cultural and political capital, tribal identity.

Danças religiosas e turismo: os "tribais" percecionados como o repositório do tradicional em Goa, Índia - Que mudanças ocorrem na identidade de um grupo considerado tribal na Índia através da performance das suas danças? Qual é a influência do turismo nos seus cultos religiosos? Qual é a perceção dos outros indianos sobre eles? Para responder a estas questões, analiso, em primeiro lugar, o modo como o governo de Goa estimulou a institucionalização das suas danças. Em segundo, examino o aumento de capital político, económico e cultural do grupo de estudo de caso através da transição para a indústria do turismo. A pesquisa baseia-se num trabalho de terreno prolongado em Goa. O património de música popular é analisado a partir da perspetiva da antropologia. O artigo procura aprofundar o legado musical dos Gawda católicos, também conhecidos como Kunnbi, ainda por explorar. Sugiro que foi através do turismo que os Gawda, enquanto tribais, passaram a ser valorizados como o repositório da Goa tradicional, deixando de ser representados pejorativamente como primitivos (associados a pouco desenvolvimento), por manterem o seu modo de vida rural. Todavia, é quando os Gawda católicos 


\begin{abstract}
se tornam visíveis para os turistas e para os próprios goeses, e, simultaneamente, modernos e globais, que se dá o paradoxo de serem vistos como os que continuam práticas ancestrais. Observa-se, por isso, um processo de "invenção da tradição", não no sentido de terem criado recentemente o que é mostrado (embora haja uma uniformização para turistas), mas na interpretação que é dada aos Gawda, os quais passaram a representar a autêntica identidade goesa, através das suas danças.
\end{abstract}

PALAVRAS-CHAVE: folclorização, turismo, ritual, invenção da tradição, capital cultural e político, identidade tribal.

PEREIRA, Cláudia (claudia.pereira@iscte.pt) - Instituto Universitário de Lisboa (ISCTE-IUL), Centro de Investigação e Estudos de Sociologia (CIES-IUL), Portugal.

\title{
TRANSFORMING IDENTITY \\ THROUGH THE INSTITUTIONALIZATION OF DANCE
}

Certain Catholic Goans perform dances during religious worship that refer both to Catholicism and Hinduism. ${ }^{1}$ These religious ceremonies grant the group collective well-being while other Catholics that do not celebrate them are now slowly becoming acquainted with the dancing. From relative obscurity in the village, these ceremonial dances have transitioned to urban stages through tourism, where they are performed in what is perceived to be unique to this group as compared to other Goans - their cultural heritage. I focus the analysis on the transformations that occurred in the Catholic Gawda's tribal identity through the visibility gained by the performance of their dances.

Since they are considered the most "backward," in part because they lived near the forest, the Gawda are perceived by other Goans to be the original

I The ethnographic research in Goa for my PhD, on which the paper is based, was funded by a fellowship of Fundação para a Ciência e a Tecnologia (SFRH/BD/19065/2004). Acknowledgements are due to Centro de Investigação e Estudos de Sociologia (CIES-IUL) for funding the proofreading. I am grateful to former PhD supervisor, Rosa Maria Perez, for the debate. No amount of gratitude is enough to thank the patience and time of the performers from Avedem, Goa, since I began fieldwork there in 2006. My attempt to discuss the topics approached in this article has been influenced most saliently by the ethnomusicologist Shubha Chaudhuri, who helped me in structuring the text and in extending the case study to the state of Goa. Transcriptions of song lyrics in Konkani and further translation were made possible with the invaluable help of folklorist Ullas Dessai. I thank Alito Siqueira, Vinayak Khedekar and Kala Academi for the information provided. Many thanks to the translators Eduardo Crespo and Nandini Chaturvedula for the revision and suggestions. I am indebted to the anonymous reviewer of Etnográfica for the insightful comments. I thank Inês Lourenço and Rita Cachado for their comments. To Marta Prista I direct my gratitude for the insights on the structure of the paper and the theory. I have particularly benefited from the detailed comments of Maria José Araújo in formulating the argument and in rethinking my perspectives. 
inhabitants of the area. This representation suffered a transformation because in the $21^{\text {st }}$ century they have become a repository of traditional Goa by representing an authentic Goan identity in their dancing. This is believed to be originally Goan and pre-colonial, hence revealing Indian authenticity. Located in the considered "lower tiers" of the caste system, the Gawda's social status has been revised through the qualification of their dancing as vernacular, both by foreign and domestic tourists and by Goans themselves. The relevance of their dancing as integral to Goa's cultural heritage has therefore provided the Gawda with integration into Goan society, starting from the bottom of the social system. Across India folk dances have witnessed change with transitions to public performance (in fact a pan-Indian phenomenon). ${ }^{2}$ The paradox of the situation lies in the fact that as the Gawda gained visibility vis-a-vis the outside world while experiencing modernization and globalization, their identity suffered the opposite effect, being reified as "timeless," or frozen in time. Hence, there is an "invention of tradition" (Hobsbawm 1992 [1983]), though this does not necessarily imply that what is presented in their performances is a fabrication (although they are homogenized for touristic performance). Instead, the "invention" is symbolic in nature as put forth by Hobsbawm (1992 [1983]: 1), revealing a stereotypical perception of the Gawda's identity under the assumption that they carry out ancestral practices. Therefore, the categorization as tribal linked to the Gawda remains unchanged, though now attached to a whole new meaning.

Enabling this identitary transformation has been the fact that the Gawda may be considered either aborigine or indigene in transnational indigeneity discourse because their members are considered the initial inhabitants of a location. Questions, however, arise: how do groups considered tribal transform their identity in today's modernizing India? What role has the government and tourism played in this process?

The Gawda's invisibility has been conferred by their omission from the literature on Goan music, both in references to their caste/tribe as well as to the style and scope of their performance. However, some works have focused on the Gawda's musical heritage (Henn 2003; Henn and Siqueira 2010; Fernandes 2009; Pereira 2010, 2012; Bara 2013), and the dhalo ritual, dance and songs (Khedekar 2004; Dessai 2006). Recently, the project Archives and Research Centre for Ethnomusicology (ARCE) of the American Institute of Indian Studies (University of Chicago) in New Delhi, coordinated by the ethnomusicologist Shubha Chaudhuri, has enabled online publication of much of the Gawda's musical repertory. ${ }^{3}$ The existing studies on Goan music have

2 This information was provided by the ethnomusicologist, Shubha Chaudhuri, to whom I thank.

3 This repertory can be found at < http://www.folkways.si.edu/music-of-goa/india-world/music /album/smithsonian > "Music of Goa. Various Artists ARCE00034," audio, Smithsonian [continues] 
mainly focused on the dominant culture displaying a mixture of vernacular and Western influence. The Brahmins and the Chardé, considered Catholic high castes, due to their former proximity to Portuguese colonizers (cf. Newman 1984) had the literacy and authority to define Goan culture in order to distinguish it from Portuguese culture (Sardo 2011). In regard to the scope of their performance in tourism, literature makes no reference to the Gawda, focusing on broader-scale phenomena arising from the transformations in the tourism sector after the annexation of Goa to India, such as: the trance music festivals (Saldanha 2005; D’Andrea 2007; St. John 201 1); lifestyle migrants (Korpela 2016); Portuguese heritage and Goa as an exotic destination for Indians (Perez 2006; Trichur 2007; Gupta 2009); and the impact of the tourism industry (Wilson 1997; Alvares 2002; Noronha et al. 2002; Breda and Costa 2012). As such, it is necessary to document the relationship between the touristic performances of the Gawda and their religious ceremonies outside the events, in the "back stage" (cf. MacCannell 1973).

The Gawda are predominantly farmers who towards the end of the $20^{\text {th }}$ century gained some economic mobility thanks to land reforms and government education grants as a result of their Scheduled Tribe status. The majority of the Gawda are Hindu (57\%), the remainder Christian (Government of Goa 2005). They can be divided into three groups: Hindus, Catholics and Neo-Hindus. The Hindu Gawda are known as the Konkanne Gawda, a term which refers to an inhabitant of the Konkan area (where Goa is located) as well as to Hinduism (the original religion of India). ${ }^{4}$ The Catholic Gawda are the section of the Hindu Gawda that converted to Catholicism through contact with the Portuguese when the latter colonized Goa from the $16^{\text {th }}$ century onwards. ${ }^{5}$ The Neo-Hindu are the Catholic Gawda who performed the Shuddi, a Hindu purification ceremony, between 1926 and 1932, and have since become Hindu.

[continued] Folkways - Archives and Research Centre for Ethnomusicology - ARCE), online resource (last access in January 2017). The ARCE has one of the most extensive audiovisual repositories of the oral traditions and performing arts of India (see "Ethnomusicology: the Archives and Research Center for Ethnomusicology," < http://www.indiastudies.org/ethnomusicology >).

4 The term "Hindu" is derived from "Hindustan," the peninsular historic region in southern Asia where India is located, and has been gradually used to designate those who practice a local Indian religion (Fuller 1992). The denomination Hindu has come to include a large number of distinct practices, as well as groups diverse in their worships and internally varying (Babb 1975). In the case of the Hindu Gawda, contrary to other groups, their religious ceremonies are celebrated away from the large Hindu temples, belonging to the castes located higher in the social system, rather practicing these ceremonies in small temples adjacent to the forest. This segregation, which is also spatial, has reinforced within contemporary tourism the perception of the group as the original inhabitants of Goa under the assumption that they perpetuate original rituals.

5 The conversion of some Hindus to Catholicism under Portuguese rule resulted in the following Christian castes, with a certain attenuation in the ritual pollution: Brahman, Chardo (combining ex-Vaishya and ex-Kshatriya), Sudra, and Untouchables. 
The Gawda are placed in the lower fringes of the social scale by the remaining castes, classified either as tribal (hence excluded from the caste system) or regarded in the social space between the Sudra and the Untouchables, at the very bottom of the scale (Pereira 2009). In Goa in 2003, the Gawda, Kunnbi and Velip gained the status of Scheduled Tribe. The arguments for this administrative classification were based on their economic and educational backwardness and their being considered the first inhabitants of Goa. ${ }^{6}$ In India, a group within the population which has been given tribal status will enjoy the benefit of political instruments by the government in order to assure its members' educational and economic mobility by attaining the administrative classification of "Scheduled Tribes," who are $8.6 \%$ of the total Indian population and 10.2\% in Goa (Government of India 2013: 126). The categories "caste" and "tribe" are not mutually exclusive, but contiguous, as observed among the Gawda at a social, ritual and administrative level (Pereira 2009).

This paper is based on ethnographic research conducted over a year in 2006 and 2007 in Goa among Catholic Gawda. Goa is located on the southwest coast of India. The territory was colonized by the Portuguese in the $16^{\text {th }}$ century and was only integrated into the Republic of India by annexation in 1961. In 1987 it became one of the youngest states of India, months after Konkani and Marathi were declared the official languages of Goa. Portuguese influence, largely through Catholicism, is visible even today, particularly in the Catholic population in the central coastal area - nearly one fourth of the total population (25\% according to the $201 \mathrm{l}$ Census), while the rest of the territory is markedly Hindu (66\% in 2011$).{ }^{7}$ Research was conducted in a small village in the taluka of Quepem, a majorly Hindu area in the south of Goa. ${ }^{8}$ This taluka holds the largest proportional percentage of Scheduled Tribes in Goa, 34\% as of 2005 (Government of Goa 2005: 24). The village of Avedem's population totals 1,650 inhabitants, ${ }^{9}$ one third of which are Gawda, equally divided between Christians and Hindus.

The analysis is grounded in the ethnographic method, namely including participant observation, interviewing, transcription of song lyrics and a structured field diary. The participant observation through daily interaction with the Gawda allowed observation of the identity transformation within the group, by following its members at home, in the rice fields, at prayer, annual religious ceremonies and in their performances for tourists, all of which has been

6 As stated in a booklet of Goa State Scheduled Tribes Finance and Development Corporation Ltd., Panjim, 2005, p. 1 .

7 See 2011 Census for data on religion by states of India, in "Religion PCA" available at $<$ http://www. censusindia.gov.in/201 lcensus/Religion_PCA.html > (last access in January 2017).

8 A taluka consists of several villages and a town. The state of Goa is divided into eleven talukas.

9 See 2011 Census data at < http://www.censusindia.gov.in/pca/SearchDetails.aspx? Id=714163> (last access in January 2017). 
systematized in a field diary. On one occasion I was invited to take part in the Gawda's dance during the ritual of dhalo, where I was able to experience firsthand their embodied practices, and this communion led women in the group to provide me with further data they had previously withheld. Several in-depth, semi-structured interviews conducted with the Catholic Gawda enabled me to document the evolution of the dance group and rituals over the years; the religious beliefs involved in the practice of rituals; and song lyrics that were transcribed. Hindu Gawda and members belonging to other castes were also interviewed, as were cultural and tourist agents, and even tourists, in order to provide a broader context of the Catholic Gawda's position in modern Goa.

This case study of Catholic Gawda therefore focuses on a village in the predominantly Hindu southern Goa. Given that their self-designation as Gawda diverges from their being known to the outside as Kunnbi, I begin by analyzing the differences and similarities between both terms, in order to grasp how these "Kunnbi dances" have been socially constructed as vernaculars of Goa. Then I provide a description of a same practice, dhalo, in a touristic performance where it is danced before an audience, and in a religious ceremony where it is performed in private, examining Hindu influence in their Catholic worship and providing excerpts from song lyrics. In the analytical sections I shall begin by comparing religious ceremony with touristic performance, given Goffman's concept of ritual as a closure of borders (Goffman 2005 [1967]), then verifying how the Gawda's performances, as any other touristic phenomenon, are an identity construction directed towards tourists, while still remaining an integral part of the Gawda's own identity (cf. Boissevain 1996). Though these public performances produce identity in the sense that they lead to gains in political, economical and cultural capital for the Catholic Gawda (and are also a means of reducing social inequality), they are also a product of transformations in their own identity, set in a broader structure of political, economic and cultural changes across the state of Goa. This transformation hence reveals an "invention of tradition" (Hobsbawm 1992 [1983]) not in the sense of a fabrication of the content of the Gawda's performance, but rather by attaching to the Gawda the perception of a repository of traditional India. This perception is stimulated by the selected form in which the Gawda perform before their audience through the use of costumes and homogenization of their performances.

I propose that through a process of commodification of culture and subsequent validation in the public realm, the tribal identity attributed by other Goans to the Gawda has shifted from being regarded as backward to valued as traditional and respected for maintaining and promoting cultural heritage. This process arises in the wake of a global trend, in which marginalization and backwardness are reversed and promoted to culture; in this case, the Gawda's musical manifestations have been objectified as Goan culture (cf. Handler 1988). 
Together with this conclusion, over the course of this research two additional findings surfaced. Their dancing includes both Catholic and Hindu references, which is understandable given the context of Hindu hegemony, although until recently the Catholic Gawda were among those who lived farthest away from the remaining castes (cf. Pereira 2009). The second unexpected finding was a shift in the way the group perceives its own dancing, now valuing what was previously disregarded. When I revealed my interest in their dancing, a member of the group responded: "Why study us, when there are more interesting dances such as the ones in higher castes that even speak Portuguese?" [Tina, age 51$].{ }^{10}$ Later on, they allowed the transcription of song lyrics (until then only transmitted orally) for the first time in 2006. These songs were also for the first time translated from their native Konkani language into Portuguese on the same occasion. ${ }^{11}$ It is important to point out that the translation of the Gawda's songs took place under the condition that, at most, small excerpts would be published, in order to prevent plagiarism from other groups. ${ }^{12}$ One year later, with the influence of tourism being felt by the group, they began to reflect upon the value of their dancing, fearing identitary misappropriation, because they themselves view their dances as part of a unique heritage, much like other Goans view them. This perception of singularity strengthens the idea of a genuine India, untouched by outside influence, often through the strategic avoidance of other castes (through endogamy and commensality) and through isolation, which is now valued - such as the present study case shows.

To put this strategy into perspective, the Gawda, like most of India's population, live in rural settings $(68.8 \%$ for the general population, according to Census 2011, in Chandramouli 2013: xi), where most community members have few resources, aggravated by government policy, which left them largely illiterate. Recent efforts in education initiated towards the end of the $20^{\text {th }}$ century have granted younger generations the access to new economic and educational capital. As is the case with their religious worship, which includes practices unique to them within the Catholic population in the village, in their touristic performance the same strategy of avoiding other castes and musical groups is employed as a device for the closure of borders (cf. Goffman 2005 [1967]). The Catholic Gawda also prevent the digital reproduction of their songs in order to minimize the risk of being copied, which singles them out from other musical groups with equally scarce resources from India and other

10 Tina is not the interviewee's real name, and is used here and in later quotations within this text in order to protect the personal identity.

11 On the other hand, Goa's elite's songs such as mando had been throughout the 20th century subject to translation due to influence by the West and their performers being literate and close to the colonial establishment (cf. Sardo 2011).

12 Plagiarism is presently difficult to control, since recent technologies such as mobile phones equipped with video cameras may record the touristic performances. 
countries who have chosen to benefit from modern technology to maximize their exposure (cf. Naithani 2005; Hayward 201 l; Nhlekisana 2011 ).

\section{GAWDA AND KUNNBI: GROUP'S STATUS THROUGH NOMENCLATURE}

The intangible heritage built socially as a vernacular expression of Goa is directly attributed to the Gawda and also to the Kunnbi, who share several cultural and socio-economical similarities, as the anthropologist Robert Newman points out:

"Among the lower castes is a large group who, while Catholic or Hindu, particularly resemble the tribal population of other areas of India. Known as 'Gavda' or 'Kunnbi', they share much the same appearance, folk culture and socio-economic position, despite their religious affiliations. Because of this, they may be said to form the solid base of Goan regional culture: Konkanispeaking, having a common world-view of a syncretic Hindu-Catholic variety, with a shared livelihood based on agriculture, fishing and liquordistilling" (Newman 1984: 436).

These similarities led to the dancing in question being attributed to both Gawda and Kunnbi, being frequently referred to as "Kunnbi Dance," as they are usually presented in the Kala Akademi Lokotsav (Folk Festival). ${ }^{13}$ Curumbim is the Portuguese word used by the Catholic elite of Goa to translate from Konkani both Gawda and Kunnbi (Pereira 2009). However, Gawda and Kunnbi are distinguishable by religion, the villages and regions of Goa they inhabit and also their economic status. Both groups employ the same points to argue their uniqueness when they are identified as similar by outside observers. Though they consider themselves different based on these three criteria, the Gawda and Kunnbi groups have not been isolated from one another and they have long intermarried as well.

In some villages, nonetheless, the Gawda consider themselves of higher comparative social value than the Kunnbi, because they regard the Kunnbi as backwards and as the inhabitants of the top of hills. The Gawda claim they are called Kunnbi by outsiders due to their social and cultural proximity, although they are in fact Gawda.

Moreover, when another similar group of a different religion resides in the same village, the case-study group in my research prefers to be regarded as Gawda, as has been verified in other locations in Goa (cf. Montemayor 1970; Khedekar 2004; Government of Goa 2005). For these reasons, rarely are both Hindu and Catholic Gawda found in the same village, as occurs as well with

13 See an excerpt of their performance in 2015 at < https://www.youtube.com/watch?v=BVUQ38 hyVA4 > (last access in January 2017). 
Hindu and Catholic Kunnbi (Silva 1993 [1989]). The homogenization of the two groups in the same village by other castes, who regard them as similar, leads to the maintenance of a certain distance in terms of the groups' nomenclature, so that there may be balance in their social relations. This contrast claimed by both Gawda and Kunnbi is hence revealed specifically through:

- religion - the Catholic Gawda say the "Kunnbi are Hindu," as the Hindu Gawda say the "Kunnbi are Catholic;"

- village population - in the Canacona area (southern Goa) there are no Catholic Gawda and the Hindus define themselves as Kunnbi; in Ponda villages (central Goa) it is said there are no Catholic Kunnbi and the Hindus declare themselves to be Gawda;

- regions of Goa - there appears to be a greater number of Kunnbi in Canacona (most Southern region of Goa) and the number of those who identify themselves as Gawda appears to increase as one advances from South to the Centre and North of Goa;

- economic status - associated to the Kunnbi is a notion of economic backwardness due to the fact they have traditionally lived in reclusive areas or in the mountains, which leads to a reluctance to being recognized as Kunnbi, in contrast with the Gawda.

Research sheds light on this complexity within only one village: when questioned, some interviewees designated the Catholic and Hindu Gawda as Kunnbi/Curumbim; while others separated the group in classifying the Catholic Gawda as Kunnbi and the Hindu Gawda as Gawda; others would make this distinction in the opposite manner (Catholics as Gawda and Hindu as Kunnbi). However, in the case-study village, both the Catholic and Hindu groups refer to themselves as Gawda and for that reason Gawda is the term used to refer to them in this article. Two women, for instance, who travelled from neighboring villages in another area, Salcete, to marry in this village, referred to themselves as Kunnbi/Gawdi (being from Betul and Raia, where there were no Hindu Gawda, there was no need for a terminological distinction between Catholics and Hindus). Also, when requesting the status of Scheduled Tribe, the Hindu and Catholic Gawda together assumed themselves as Gawda, according to the administrative data of the Talathi, which initiated the attribution of this status to the Gawda, Kunnbi and Velip (Pereira 2009).

The media, literature and museology have displayed this classificatory ambiguity by identifying the group under analysis here interchangeably as Gawda or Kunnbi. ${ }^{14}$ Such is the case of the Goa State Museum in Panjim where the 
dancing group is referred to as Kunnbi. In one of their performances at the folk festival organized by Kala Academy in February 2006 they were introduced as "tribal of Goa, Kunnbi-Gawda," bringing the two categories together. In the media, the dancing group named Keniabhat Mahila Mandal "the dancing women of the Keniabhat neighborhood," from the village studied in this research) is usually identified as Kunnbi. This, according to the group's director, is due to the fact that when they first performed in Panjim in 1972 the information provided by the group was misleading: they were introduced by the Department of Art and Culture as Kunnbi in order to distinguish them from the Hindus of the Mardol village, Ponda, identified as Gawda. They used therefore the criterion of religion to distinguish the two groups, calling the Catholics Kunnbi and the Hindus Gawda, and for that reason the group was from then on designated by outsiders as Kunnbi.

The fact that the group's status has been negotiated shows us how it is neither stable nor permanent, often challenged by its own members in their group's nomenclature and not consensually accepted by the other castes (cf. Pereira 2003). The dance group is also known as Kunnbi as are other groups of Goa due to similar cultural references linking them to that social category, a classification which is disliked by the group's members. Often the group is distinguished from other Kunnbi dance groups by their director's name, Amélia Dias.

This process has consolidated their identity among Goans and other Indians as Kunnbi and "tribal" (associated pejoratively to backwardness), but this perception is now shifting to a more positive light through the inclusion of their practices, still considered tribal, in Goa's cultural heritage. In fact, Kunnbi dance as a touristic item became widespread in Goa, performed in tourist boats and by school children in their functions. In the present case study, this distinction between Gawda and Kunnbi has become instrumental in the group's affirmation of not being classed as Kunnbi by making use of their dance's identitary influence. By generating greater value for their own status through performance, the Gawda look to establish the Gawda identity as more socially valuable than that of Kunnbi.

\section{DHALO AS TOURISTIC PERFORMANCE AND RELIGIOUS PRACTICE}

Catholic Gawda women's main celebration is dhalo, in which they dance and sing dhalo (the same name for a ritual and a form of dance) and fugdi. They also perform dhalo and fugdi during some of their farming work, as well as

[continued] preserving Kunnbi Heritage," The Navhind Times, July 16 $6^{\text {th }}, 2005$, p. 3; "Lokotsav 2006, Folk Festival," Gomantak Times, February 26 ${ }^{\text {th }}, 2006$, p. 13; "The Kushawati heritage trail," by Prajal Sakhardande in the blog Everything Under the Sky (< http://vishaalbhat.blogspot.com/2005_1l_0l_ archive.html >, last access in January 2017); "From Carnaval to Carnaval," by Maureen Álvarez, The Navhind Times, February $24^{\text {th }}, 2006$, p. 7. 
"wedding songs" at their marriage ceremonies. The men's ritual is intruz, which coincides with carnival in which khell (a Gawda-specific form of theater) and mhell ("being together") is performed when visiting neighboring villages. In the same fashion, Hindus practice shigmo, which occurs around the same time and in which requests of protection and fertility are renewed. The Hindu and Catholic Gawda's songs are alike in their representations of everyday life and of nature, and are different when relating to Catholic and Hindu entities, as would be expected. To better grasp how the Gawda's religious dancing reach the stage, I shall first describe one of their touristic performances as well as one of their religious ceremonies, dhalo, taking place in the same year.

One evening in October 2007 I was invited to accompany the Catholic Gawda to a performance for tourists, as I had been several times before, joining the women in their makeup preparations for the show. They then dressed in their traditional outfit, which distinguishes them from the remaining castes who wear untied, full-length saris. The sari used by the Gawda women is the kapod, a red and white checkered cotton knee-length sari, tied at the shoulder (deutelli). Finally, the women adorn themselves with accessories, a necklace of black and golden beads $(a z) ;{ }^{15}$ another necklace (gholshiri) made of coins (povnam) and a red stone (poule); an earring with an additional chain attached to the woman's hair (sorpinati); the bracelets (kankon) and marigolds in their hair. The men collect their musical instruments, already adorned in a kneelength white cloth with red stripes tied along the waist (toalo) and a white sleeveless undershirt (banniyan). ${ }^{16}$ This traditional costume is an important identitary element which distinguishes the group from the remaining castes and evokes the past, social roles and status, having a specific association with farming work, given that the majority work in the field. The women, for instance, would not be able to bend over in the rice floodplains without wetting their clothing were the kapod not knee-length, as opposed to longer saris (Pereira 2010).

Upon finishing the aesthetic preparation, we moved on to the venue of the performance. We crossed the rice fields (freshly green due to the recent monsoon) in a pickup truck to arrive at the Palácio do Deão ("Dean's Palace") ${ }^{17}$ in the neighboring city of Quepem. A gathering of people in red kapods and white scarves passed along outside the palace toward the performance venue, which was surrounded by canopies of the garden's trees and filled with seating for spectators, where the Palace's owners awaited the group. The audience was a

15 Which for Hindu women is one of a set of symbols that attest to the fact that they are married.

16 In day-to-day life these outfits are usually only worn by elderly women and adult men, young women only tend to wear them for these occasions.

17 Recently restored in the 21 st century for tourism purposes, the palace has Indo-Portuguese traits and dates back to the 18th century, as can be seen at < www.palaciododeao.com > (last access in January 2017). 
group of Portuguese tourists who had purchased an organized tour package to visit Goa.

In the performance the men play the musical instruments and women sing and dance. A male Gawda begins the performance playing a crescendo rhythm with sticks on a drum (ghumat, an oval shaped clay drum covered on one end with lizard skin), and is joined soon after by other local percussion instruments, such as the kaansaalem, dhol and taaso. This is followed by the rhythmic stomping of the dancers' feet, intensified with the jangling of their bracelets, and finally the voice of a Gawdi singer. For over an hour the tourists listen and applaud. The western spectators remarked they were surprised because it transported them to an exotic setting, alien to their usual references. Since the performance included specific parts of their rituals selected backstage for presentation, the audience gauges the group's identity through their uniform performances and carefully composed costumes.

To this exaltation of the senses adds the taste experience, when the tourists dine on Goan food in an Indo-Portuguese palace hall, in which the Portuguese historical memory and identity also play an important role for the tourists while in Goa. The Gawda were perceived as unique by the tourists and one of them wished to own a recording of their music, to whom I explained the groups' fears of their repertoire being copied, which has impeded recording their performances:

"We have visited several parts of Goa but hadn't yet seen anything like this, this is an authentic Goan group, are they not? They remind me of other indigenous, tribal groups of other countries. How can I get hold of a CD or DVD of their performance? I am deeply enjoying Goa and this was one of my favorite moments, very unexpected. This palace feels like Goa, as well as Portugal" [António, Portugal, age 42; translated from Portuguese].

In spite of living within two kilometers of this palace, the Gawda's very first visit occurred only in 2006 when they performed there, and to this date their contact has been limited to the external architecture; they have never been inside. The Gawda's weak socio-economical status through the eyes of other castes has led them to display a corporal habitus (Bourdieu 1972), which shows their unease in these surroundings, known to them only through their performances. Adult and elderly Gawda had been farm laborers (mundkar) in the rice paddy fields and coconut palms belonging to large Catholic landowners or to the Hindus of more socially valued castes. They were paid in a share of crops, with no exchange of money, which they were unaccustomed to utilizing for economic transactions. These Gawda were widely targeted by policies of dominance that only subsided after the implementation of agricultural reforms that took place after the annexation of Goa in 1961, as well as 
the government subsidization after their classification as a Scheduled Tribe in the early $21^{\text {st }}$ century. This highly unequal social structure barred them from achieving social mobility and in a way limited them to only socializing in a restricted circle within their own group, which has led to them being regarded today as unique and "uncontaminated."

This social exclusion is hence the circumstance that allows them to be valued and perceived as a repository of genuine Goan identity nowadays. This process led to the increase of their cultural and "identitary" capital, due to the dances commodification, which enabled them to visit new locations and have contact with different social entities with greater economic and cultural capital.

Later in October 2007 into early November I witnessed the same dancing but in the religious dhalo ceremony. As a ritual, its role in the Gawda's annual calendar is of great importance. It is the moment when women dance within their neighborhood, performing the same dances yet, unlike the performance described above, hidden from the exterior (once more the closure in Indian society). The dhalo includes practices unique to the Gawda, not shared with other Catholics in the village, who have little knowledge of it, revealing the identitary distance between groups.

The religious dhalo takes place at an auspicious time because there is plenty of food after the rice harvest, which is the foundation of their diet. In the Catholic liturgical calendar, the dhalo takes place before the "day of souls" or of "the departed," alma dis, on November $2^{\text {nd }}$. As a dance, women perform it splitting along two parallel lines, facing each other with joined arms, one line coming forth singing, stepping back, then the other line repeating the pattern. This back and forth movement justifies the dhalo's (or dhalop's) etymology, signifying "flowing" or "swaying" in Marathi (cf. Dessai 2006).

Women commence the dance three, five or seven nights before November $2^{\text {nd }}$, always on odd numbered nights. According to Gawda women, this is because odd numbers symbolize fertility and are auspicious. They start the ritual either on a Wednesday or a Sunday, the days of Gaon-Purush, the only days not dedicated to Hindu gods in the Hindu weekly calendar, which is respected by the Catholic Gawda. Gaon-Purush is a protector spirit with a human form, their ancestor from whom they trace the genealogy (whose name derives from the word for "village," gaon, and Purush, the original inhabitant of the vaddo, or neighborhood). Dhalo is a propitiatory dance, seeking to ease Gaon-Purush into not disturbing the deceased and their living relatives on the day their souls return home, the day the church remembers its dead (Pereira 2009). This ceremony stems from the Hindu cult of diwali (in short, "festival of lights"), ${ }^{18}$ in the words of one of the performers: 
"Our Hindu ancestors worshiped in honor of the dead on diwali, but upon conversion to Catholicism this was prohibited by the pakli ['white', meaning 'Portuguese'], which led to the celebration taking place on alma dis, when the Church remembers its dead, usually after diwali. By this time the rice has been picked, and alma dis takes place before diwali so he [GaonPurush] does not get irate for our continuing to remember the dead on dhalo" [Maria, age 59].

This explanation, the same one given by other women in the group, is of relevance for demonstrating the Catholic Gawda's logic in negotiating rituals between Catholicism and Hinduism. Together with Catholic practices, they also adapt and practice rituals with Hindu references passed down by parents and relatives (Pereira 2009), as the following description of the religious ceremony shows.

In dhalo ritual there is a division by gender, in which the women sing and dance and the men watch; in the men's rituals, intruz, the opposite occurs. In 2007 the Catholic Gawda began dhalo on a Wednesday, one of Gaon-Purush's assigned days, as already mentioned. That evening, as in the following ones, the women removed their shoes (as do their Hindu neighbors in their religious ceremonies) and sat in a circle around the sacred space of the maand, a yard located in front of the home of its guardian, the maandkar (in other cases, in front of Hindu temples), where the religious dances take place. The maandkar lights the holy lamp (deuli), as do the Hindus in their ceremonies, thus commencing the dhalo. The maandkar then carries the lamp towards the cross located in the maand, where Gaon-Purush can be found on such nights, according to the Gawda. This is the reason why Catholic prayers are offered to Gaon-Purush, such as Hail Marys and Our Fathers, also invoking Goenchen Saibini, "Our Lady of the Village," in this case, "of Conception", the patron saint of the parish.

After praying, the women begin their dancing and sing one song; an excerpt of its lyrics is here presented:

Dhalo

Row 1 Amgelea Maandarin dovorla narl

Row 2 Te nallak paio tumi podai ghe, aichean dhalo tumi lo korai [...]

Row 1 Toleantali dadhoy tolem firta Toleantali dadhoy tolem firta

Row 2 Saibinicho roth bado maandari khelta re dhalo, Saibinicho roth bado Maandari
A coconut is in our maand Lean on to Him, displaying respect in your prayer, we shall commence dhalo as from today [...]

A fish swims round in the lake A fish swims round in the lake Seems like the cart that goes round like Our Lady in the maand Seems like the cart that goes 
khelta $[\ldots]$

Row 1 Ogi eili ogi eilo kitya eilolim gue?

Row 2 Ami eiloli, ami eilolim Katarina soirikek gue $[\ldots]$

Row 1 Ghodé sotri laun tankam bolonn hadai gue

Row 2 Sov vorachem tat tanka zevon vadai gue $[\ldots]$ round like Our Lady in the maand

Why have you come so slowly?

We have come to propose marriage to Catarina [...]

Send the horse and the sunshade to call for them

Feed them at 6 in the evening

These verses are sung by both the Catholic and Hindu Gawda women, noting the similarity of the cults. When this collection of songs of the Catholic Gawda was compared with the one of the Hindu Gawda of the same location, Quepem, carried out by the folklorist Ullas Dessai (2006: 7-19), there was a strong resemblance in the verses. Therefore, the Catholic Gawda adapt the hegemonic Hindu references by maintaining them in most verses, replacing Hindu gods with Catholic deities in certain parts, as the excerpted lyrics show. We find a reference to a coconut, essential to any Hindu practice (puja), as well as a horse and a sunshade, calling upon the Hindu groom (before he meets his bride in a marital ceremony) and the wooden cart, which is the most privileged means of transportation for parading Hindu deities around their temples during annual festivities such as zatra. ${ }^{19}$ However, in this case it is Saibini, "Our Lady" who is taken on the cart, while we find in the Hindu version of the song the goddess Santeri (Pereira 2009). Hence the song in both Catholic and Hindu versions presents the same structure, save for the verse in which Santeri is replaced by Saibini.

The way dhalo is practiced by the Catholic Gawda and the lyrics in its songs show a religious pluralism with both Catholic and Hindu references when observed from an outside perspective (etic); contrasting their practices with those of other Catholic castes who consider themselves to have ways of acting more in line with what they conceive as a legitimate Catholic religiosity. However, from inside (emic perspective) the Catholic Gawda regard their religion authentically only as Catholicism. In their native language, Konkani, they refer to it as cristao dharma, using the word assigned to religion in India that is derived from the Sanskrit dhri, meaning that which has been established or has become firm. This is only approximate because this word has no direct translation into western languages nor a semantical equivalent (Flood 1996:

19 Zatra is the annual pilgrimage to the temple to celebrate the anniversary of the tutelary deity, according to the Hindu lunar calendar. 
52)..$^{20}$ Therefore, dharma has a specific meaning that differs from "religion." Just as the Hindu dharma has several gods, to the Catholic Gawda Catholicism also harbors several deities and references, and the word dharma is used to refer to Hinduism and Catholicism as two distinct beliefs, but in an inclusive manner, in which the worship of one does not preclude the worship of the other (cf. Pereira 2012).

Returning to the ritual in itself, contrary to the performance for foreign and Indian audiences, where the costume is stereotyped for every performer, this ritual is more informal and youth can dance in everyday clothing such as jeans, t-shirt, skirt and blouse, or the vistid ("dress" in Konkani); adults dance with a cotton sari or vistid; while elderly women wear their traditional dress, the kapod, tied in a knot over their shoulder, or the vistid. They wear ornaments ranging from gold to plastic, depending on their personal choice and therefore quite different from the standardized aesthetic effect when performing for tourists.

On the final night of November $1^{\text {st }}$, "all saints day" before the souls of the deceased are believed to "come home," the celebrations go on until early morning in order to coincide with the time when these souls are believed to visit their loved ones. A few hours later, on the morning of November $2^{\text {nd }}$, the Gawda attend mass at their church together with the village's other Catholics, where a packed congregation remember their dead relatives and take part in the homily for their eternal rest. This is followed by a trip to the cemetery where the dead relatives' graves are decorated with colored flowers, after which the attendees proceed to their jobs.

THE DANCE AS A MOBILIZING FORCE OF POLITICAL, ECONOMICAL AND CULTURAL CAPITAL

Processes of commodification of culture such as the one the Gawda are experiencing occurred before in other countries (cf. Handler 1988), such as Indonesia, where "... practice has become performance" (Acciaioli 1985: 153). These performances by the Catholic Gawda have been included in what is called "folk dancing" in India, in regard to musical heritage of rural origin. These usually belong to groups at the bottom of the social system, be it amateurs or professionals, where dances are passed down from elders to the younger generations at social and religious functions, as well as agricultural ones, such as the harvest.

In order to grasp the transition that objectification of culture has brought upon the group, it is necessary to understand the difference between the

20 The concept of dharma has been presented in the West as a conception of Hinduism to indicate divine and moral standards of ethical conduct, requiring certain duties according to the caste of birth that are to be observed as a consequence of acts done in a previous life (Madan 2004: 3). 
religious ritual and the touristic performance (cf. Boissevain 1996), and later analyze how tourism now becomes new ground for negotiating the Gawda's identity. What sets the Gawda apart is their relationship with the Goan government and individual agencies that bring value to their tribal identity (as well as transforming it), and integrate them in Goan society by giving them visibility and a new voice. This connection between politics and culture has hence revealed itself to be intrinsic to the construction of the Gawda's identity. ${ }^{21}$

Upon comparing the two performances described above, as religious ritual and touristic event, three striking differences are apparent. First, religious cult is absent from the touristic presentations. Secondly, longer dance practices in the ritual are shortened for public performance. Thirdly, the format of the dancing and the costumes are consolidated in order to present uniform touristic performances, reserving spontaneity and creativity in dance and outfits only to the religious ceremony.

These differences are identical to those found in the case of other forms of dance that have been folklorized, becoming stage demonstrations and object of consumption by the general public (cf. Castelo-Branco and Branco 2003). Other terminology has also been used to describe similar cases in different regions, such as revival, institutionalization, objectification, commercialization, turistification, democratization of culture and mediatisation of culture (cf. Alge 2007), all used in this text to better illustrate these processes.

However, certain similarities were found between the private religious practice and the public performances. Both are rituals in accordance to Goffman's (2005 [1967]) concept, that is acts of symbolic interaction through stereotypified forms which reach beyond a mere religious ceremony. Given this conception of ritual as an element of interaction, both in the private practice and in public performance of the Gawda's dancing there is symbolic signaling - the removal of shoes in the holy ground of the maand as the ceremony begins or the use of traditional dress in public and secular stages, among other possible examples. Additionally, both are focused and delimit the group's borders (cf. Goffman 2005 [1967]). In the religious ceremony there is an exchange of cultural heritage through body language and voice in their dancing, which is orally handed down from generation to generation only among the Gawda, barring others from taking part in it, which also justifies their reluctance to record their performances in audio or video registrations, in order to better control the group's borders.

We now move on to address the political, economical and cultural changes at a national level in India and at a regional level in Goa that have allowed for the shifting of the Gawda's folk dancing to the stage and their resulting gains in capital and resources.

21 For the relation between politics and culture in the construction of identity, see A. Cohen (2000). 
The repositioning of tradition as tourism attraction is a wider process of government-driven folklorisation taking place throughout India (cf. Chatterji 2004). As a post-colonial strategy of building the nation, Indian governments have promoted public performances of folk dancing: from 1953 onward the Republic Day parades in Delhi (annually on January $19^{\text {th }}$ ) have featured performances of folk groups from each state, where each wears matching costumes and rehearses a standardized performance (cf. Tarabout 2005). The following year, 1954, the Folk Dance Festival was created (Tarabout 2005). These strategies sought to promote a common Indian identity through integration of "tribal" art forms as "authentic Indian culture" (Ashley 1993).

Politicians of regional governments, just as politicians in Goa, have resorted to the same strategy, seeking to present a state identity distinct from other states. For this reason, the Gawda, known as "tribal" and a part of "Goan authentic culture," have been promoted by the regional government. This promotion, again, is in itself a postcolonial tool of building the identity of the state.

This process of folklorisation started off slowly after Goa's annexation to India in 1961. In 1987, Goa became a state of India and the tourism industry settled in the region, now requiring the services of local folk groups (cf. Sardo 2011). Following this, the Gawda began to be regarded as a form of vernacular culture of the Goan state, and consequently "authentic." Authenticity meant that which was original, in other words, a present-day social construction that remits to a past that is perceived as genuine (cf. E. Cohen 1988; MacCannell 1973; Wang 1999; Korpela 2010). In the case of the Gawda this authenticity invokes an imaginary setting in which their dancing is perceived as "pre-Portuguese heritage," being pre-colonial and original of Goa (Pereira 2010). The cultural agents of the government of Goa (the Directorate of Art \& Culture and its institutions, such as Kala Academy) have wished to portray Goa's culture in stage demonstrations in national events as well as in international ones, such as when the Catholic Gawda performed in Russia in 1978. This institutionalization sought not only to promote tourism economically, but also to use it to benefit certain political interests.

The global trend of democratizing culture is also felt in Goa, where these heritagisation processes are no longer restricted to the dominant classes' cultures, and today include alternative voices such as the Gawda's. The section for "Goan Folk Dances and Art Forms" of the Department of Tourism of the Government of Goa has spread throughout India Goa's cultural singularity when compared to India's remaining states, founded in a combination of vernacular and colonial legacies:

"Goa has a unique cultural heritage, rich and lively and it is known for several folk festivals and performances. [...] Many castes, sub-castes and tribes mingled in its social texture in Goa's long history [...]. The traditional 
folk music and dances have continued uninterruptedly, while the influence of the Portuguese music and dance on the local culture has helped evolve new forms. [...] The diversity of these cultural influences makes Goa distinctive although it shares in a general way the culture of the coastal Konkan strip" (Department of Tourism's website). ${ }^{22}$

The Directorate of Art and Culture has also continued to promote its state's folklore, seeking to fulfill the goal of "preservation, promotion and development of cultural traditions of the state $[\ldots]$ by implementing the programmes towards the welfare of artists and development of Arts organisations by way of providing financial support" (presentation of the Directorate of Art and Culture in Government of Goa's website) ${ }^{23}$

The folklorization of dancing in Goa has been mobilized politically by a few Gawda who sought to gain the status of Scheduled Tribe in order to receive educational and economical benefits. Although the Gawda in this case study were not directly involved in the political struggle to obtain this status, the Gawda of other villages used their intangible heritage as well as that belonging to other similar groups to match their case for the Gawda's cultural singularity as a tribe. Consequently, the Gawda, Kunnbi and Velip were administratively classed as Scheduled Tribes in 2003 and have since gained schooling benefits, been assigned vacancies in universities and received quotas for jobs in the civil service, among other privileges.

What set the politically motivated Gawda, Kunnbi and Velip apart was the fact that the individuals involved in this process belonged to an educated middle class, politically conscious of their rights. Some of these middle-class individuals began by identifying local cultural traits that set their groups apart from other castes, leading them to revitalize certain local rituals, as did other groups of different states in the struggle for the Scheduled Tribe classification (Arora 2007). Only after 2004 was there a Gawda in the village to finish mandatory schooling and obtain degrees, which explains why before no members had sufficient educational capital to get involved in this political struggle. This data allows us to grasp the Gawda's heterogenic nature, suggesting how different the Scheduled Tribes are from one another in Goa, as they are in the remaining Indian states. In fact, affirmation of their authenticity and recognition as a Scheduled Tribe was the only strategy within the Gawda's reach to face the dominant classes. It was also one of the few means that the central government could employ to take on the present-day "silent revolution" in India, the rise of the considered lower castes towards social and economic mobility through education.

22 See < https://www.goa.gov.in/department/tourism/ > (last access in January 2017).

23 See < https://www.goa.gov.in/department/art-and-culture > (last access in January 2017). 
Through their touristic performances the Gawda have gained access to new, previously unknown spaces as well as to more publicly valued social and cultural agents. For instance, when they visit hotels, palaces, cities and other Indian states or countries, they make contact with other Indians in the arts or business with more cultural and economic capital. Another incentive has been the Gawda now possessing an additional form of income, albeit limited, according to one of the performers:

"Only through the dances I could get to know hotels where I have never entered before, or visited Delhi and Russia, which I loved. We don't earn much money, what we earn the most is to be able to travel and know new places and new people that we would not know if it were not the dances" [Maria, 52 years-old].

Cultural agents such as members of government and local hotel owners that brought on the Catholic Gawda's economic aspirations have since then also seen gains in their economic capital, revealing a mutually beneficial relationship in offering an alternative opportunity for heritage tourism to the general public that singles out Goa's culture.

As Goan culture continues to divulge musical and performing competitions, which have since arisen at a regional, state and national level, there are two types of folk groups participating. First, the professional musicians who performed traditional songs and dance, and did not alter much of their performance for the stage - collecting songs sung by their ancestors and consolidating them by normalization through rehearsal, fixed costumes or adjusting the music in order to create a uniform product (cf. Sardo 201 I). Differently, a second kind of group adapts religious dancing to the stage and only when called upon for a public performance do they leave their villages, as is the case of the Catholic Gawda, and a few selected members of these are known to be their official representatives.

The first of these events was in 1965, the Mandó Festival, in which culturally dominant music associated to the Catholic elite was represented (Sardo 2011); the Gawda have over the years participated in several folk festivals at the Kala Academy and, 43 years later, in 2008, the first Festival of the Dhalo took place. Danced by Gawda and Kunnbi, this last festival was organized by the Goan Directorate of Art and Culture, which since then promoted Dhalo and Fugdi competitions in several Hindu temples. For instance, in Chandreshwar temple in Quepem, close to the case-study village under examination here. Such musical competitions are now common all over India, often called festivals, like the dhalo festivals, and economic support given by governments (transport and preparatory expenses plus cash prizes for the winners) have also become an incentive to bring the so-called "folk" groups to perform. 
Seeing as the dhalo is built on a Hindu matrix, the Catholic Gawda are one of the few Catholic groups currently performing Hindu folk dancing in public performances such as the dhalo and fugdi competitions. The majority of the "Goan folk" groups are Hindu, as one can see by browsing through the artists listed on the website of the Directorate of Art and Culture of the Government of Goa. ${ }^{24}$

The fact that they are Catholic and performing Hindu folk dancing sheds light on the effects of their Hindu ancestors' conversion to Catholicism. Today this is shown by crossing religious borders in their public and private rituals as well as in economic capital, singling the Gawda out in Goa's cultural landscape. In other words, their religious practices prohibited by the church for not being Catholic and restricted by Portuguese colonial authorities, continued and were secretly adapted with great resilience, and are today regarded as valuable assets (Pereira 2010). ${ }^{25}$ This cultural singularity is very closely related to difference, which is one of the more elemental traits of identity (for the identity concept, see Silva 1993 [1989]). Their identitary distinctiveness is due to their difference (relative to other Hindu and Catholic castes), based on exclusion.

By integrating the Gawda's folk dancing as cultural heritage of the state the Government of Goa has recognized its value and has hence distinguished them from other castes. The Catholic Gawda, as occurred with other groups in other contexts such as Portugal, "fulfil on one side the criteria to become intangible cultural heritage $[\ldots]$ and, on the other side, fulfil the criteria of a cultural capital' $[\ldots]$ by being distinct from other $[\ldots]$ dance groups, by belonging to a rural society and by being connected to the past through their ritual performance context" (Alge 2007: 367).

The initiative behind the Catholic Gawda's dancing being institutionalized came from two educated individuals foreign to the group and the village. They mediated the rural population's relations with the social, cultural and political hierarchy, and held the power to promote their performances. The people in question were a primary school teacher working in the village and an official of the Kala Academy and current folklorist, Vinayak Khedekar. Thanks to both these individuals' contributions the group began their process of folklorization in 1972, upon their first performance in Goa's capital, Panjim; given the educational capital and distancing from local social networking of both, the dance's value as a cultural object worthy of preservation and promotion became obvious to them (cf. Wagner 1981).

24 See < http://www.artandculture.goa.gov.in/artist_search.php > (last access in January 2017).

25 However, the relationship between the church and the individual varies greatly in the region, as certain priests forbid these same rituals amongst other Catholic Gawda, as is the case of a neighboring village to the one studied. 
One significant effect of the institutionalization of the Catholic Gawda's dancing and their subsequent economic incentives has been the conservation and re-creation of the dances in religious ceremonies in the village by the younger generations, leading to an unintentional impact on the Catholic Gawda's cohesion within the village (cf. Merton 1968 [1949]). Their traditional costumes, otherwise likely to have been discarded due to only being worn by older women in the village, are now continually used in the younger Gawda's public performances. Amongst the neighboring Hindu Gawda, where dancing has not been folklorized, few young women practice forms of traditional dancing leading to a diminished cohesion in the group (Pereira 2010). Continuity is therefore a central key to the reproduction of identity.

The group's director has decided to bar any recording of their music on either CD or DVD seeking to preserve what is perceived as authentic in their performance, though other groups with similar repertoires from other villages in Goa, like the Kunnbi, also perform in the same circuits as they do. It is hence understandable that the Gawda should wish to distance themselves from the Kunnbi category in order to keep being invited to perform and to assure that their cultural resources may continue to be economically gainful. What is unusual in this particular group is its reluctance towards transformation of orality into written or recorded words through modern media, in comparison to other, equally resource-deprived groups in India and other countries. Through this they seek to secure the exclusiveness of their identity in order to assure that their distinctiveness is maintained.

\section{CONCLUSION: THE GAWDA AS REPOSITORY OF GENUINE GOA, INDIA}

The reconfiguration of the dancing for the touristic public stage also occurs in other countries, giving way to the representation of the "authentic" culture of a geographic location (like Goa), as well as the modification of identity by inclusion of the touristic performance as a part of their local culture (such as Catholic Gawda's), together with religious rituals (cf. Boissevain 1996). In the case of the Catholic Gawda this transformation had a broader impact since it affected not only cultural and touristic practice but also the group's identity as tribal. Formerly perceived by other Goans as tribal and primitive in a pejorative manner, considered "original inhabitants" of Goa and therefore backward, in the $21^{\text {st }}$ century their culture has been affirmed by tourists. The perception of the Gawda as the perpetuators of folk practices and a village lifestyle, imagined as properly vernacular and handed down over the course of generations, contrasts with the view of the urban and educated, symbolized in Goa by the mandó, associated with the elite.

Catholic Gawda, while recognizing their social marginalization vis-a-vis other Goans, also claim to integrate the upper social scale by, unlike other 
Catholics, abstaining from eating beef and pork, in accordance with the Hindu criteria of ritual purity. To maintain their purity, Gawda Catholics follow practices of endogamy and commensality. These norms are also found among other castes, but the latter among Catholic Gawda has the singularity that they only accept cooked food from the Hindu Gawda, which further maintains their distance from other Goans, because they consider other Catholic castes impure for consuming pork and beef - revealing once more both Catholic and Hindu references in their social relations (cf. Pereira 2009). The isolation the Gawda find themselves in is widened by their location very close to the geographic fringes of social space, the forest. However, this is today valued by other Goans, who appreciate their maintenance of the group's cultural boundaries, which allowed them to preserve their traditions.

Only in the $21^{\text {st }}$ century did the Gawda's dancing (formalized in 1972) benefit from the group's identitary promotion. Through the government, the Gawda and their dancing became an integral part of the display of the state of Goa's identity and became an attractive touristic product that has been promoted in other Indian states as well as internationally, hence shifting the perception of their identity by other Goans. Within this time frame a correction of the asymmetrical balance of power they faced in relation to other castes took place and deeper interaction became possible (cf. Archer 1995). The credibility of the group in the present case study benefitted greatly from the communication skills of the group's leader, who was responsible for mobilizing the performers over the course of 43 years with the support of the Government of Goa through its department of Art and Culture, which played a crucial role in divulging the group's dance.

Today, their dancing and image is being creatively reinvented in light of the Goan Diaspora: a musical ensemble of elite Catholic Goans residing in Lisbon has taken interest in recent years in "Kunnbi Dances," believing them to represent Goa's identity. ${ }^{26}$ They therefore included them in their repertoire, performing the dances in public and adorning the traditional Kunnbi and Gawda costume, the red and white checkered kapod. ${ }^{27}$ The same may be observed in the Goan Summer Festival that takes place in Swindon, United Kingdom, where the traditional costumes are adapted. ${ }^{28}$ Music, supported by tourism and globalization, has transformed the perception of the Gawda and Kunnbi both in Goa and Lisbon. The sounds of music bring forth in the present the traditions of a distant past, safeguarding their preservation for the future,

26 To know more about Goans in Lisbon, see Sardo (2011) and Rosales (2012).

27 See, for instance, < http://www.youtube.com/watch? $\mathrm{v}=\mathrm{AVjlEWHaQOO}>$ (last access in January $2017)$.

28 See < https://www.youtube.com/watch?v=_iQzhF-PxDc > (last access in January 2017). I express my gratitude to Alito Siqueira for this reference. 
hence they "[...] mobilize feelings of belonging and nostalgia, $[\ldots]$ and they may fill a place with ideas about the past, the present and the future" (Pistrick and Isnart 2013). Because the Gawda are descendants of past servants and farm workers, the immense asymmetry of power between them and the upper classes impeded an exchange of cultural practices. Only upon the Gawda's gain in cultural capital through the representation of Goa in state events and touristic performances, stimulated by globalization, has their heritage been defined as the culture of Goa and their music divulged as part of dominant Goan culture in Portugal.

There are several, equally remissive and ever shifting views on the Gawda's dancing. The Catholic Gawda select the religious dance to perform live, which is then shortened and uniformized, revealing a transformation by adapting their practices to the taste of those who appreciate not only their performance but also their identity. Their Goan, Indian and foreign audiences react to their performances by perceiving the Catholic Gawda as authentic and as a repository of a genuine Goa. That externally granted identitary conscience has hence led to a transformation within the group itself, who now, unlike in the past, value their dancing. They have not created recently what is practiced in the ritual and performed to the tourists, although it is permanently reinvented, and in this sense "authentic" (cf. E. Cohen 1988). Moreover, there is a constant process of becoming "authentic" (cf. Zhu 2012). Such is the case of the transformation of their own feelings about their embodied practice and performative experience (cf. Bara 2013). I would also add that their identity awareness, assigned from the outside, has led to a transformation within the group, in which they themselves have started valuing their dances, which were previously undervalued.

As already mentioned, unlike other "Kunnbi dance" groups, the Gawda in this study do not want their music recorded, in order to protect their cultural assets and seek closure of the group's borders as is done in their religious rituals by restricting knowledge of lyrics and choreography to the members of the group. However, in a globalization context, their performances have been recorded and published online on YouTube. ${ }^{29}$

Once the Catholic Gawda, together with the other Gawda and Kunnbi gained visibility, they become paradoxically regarded as the continuers of ancestral practices. They are now a symbol of an authentic India under the assumption that they maintain traditions untouched by Portuguese colonial influence in Goa. Saïd (1996 [1978]) theorized that most of India's colonial and post-colonial history is regarded as invention through biased Orientalist perspectives by the West. In this case, I suggest that there is today an 
Orientalist construction of the Gawda and Kunnbi's identity that pays closer attention to their "timelessness," being "exotified" by foreigners but also by other Goans and Indians.

Raghuraman Trichur (2007) has demonstrated how tourism has contributed to the inclusion of Goa in an idea of India by bringing together its Portuguese historical heritage with the British past prevalent in the subcontinent. I would add that tourism has also contributed to a greater visibility of the Gawda's cultural heritage and their group, by integrating them in Goan society through the exogenous recognition of their identity.

The study of the Gawda shows us how Indian society is in fact dynamic and permeable to outside observers, who by perceiving the Gawda's dancing as representations of an ancestral Goa have led to a slight elevation of the Gawda's social status and a valuing of their tribal image. These outside observers, both Indian and foreigners, have also affected the Catholic Gawda's self-representation by granting an awareness of their own group's identitary value.

The Gawda's status and dancing are negotiated within a historical temporality and have been targeted by multiple perceptions, depending on the context - for instance, for Goans, Indians and foreigners. The Gawda and Kunnbi, while tribal, now represent an idealized vernacular Goa symbolized by the village and traditional lifestyles by performing their dance. The meanings assigned to tribal and to their dances are therefore continuously reconfigured.

\section{REFERENCES}

ACCIAIOLI, Greg, 1985, "Culture as art: from practice to spectacle in Indonesia", Canberra Anthropology, 8 (1-2): 148-172.

ALGE, Barbara, 2007, "The Pauliteiros de Miranda: from local symbol to intangible cultural heritage?", Etnográfica, 11 (2): 353-369, available at < http://etnografica.revues. org/1997 > (last access in January 2017).

Alvares, Claude (ed.), 2002, Fish Curry and Rice. Mapusa, Goa Foundation.

ARCHER, Margaret, 1995, Realist Social Theory: The Morphogenetic Approach. Cambridge, Cambridge University Press.

ARORA, Vibha, 2007, "Assertive identities, indigeneity and the politics of recognition as a tribe: the Bhutias, the Lepchas and the Limbus of Sikkim", Sociological Bulletin, 56 (2): 195-220. ASHLEY, Wayne, 1993, Recodings: Ritual, Theatre, and Political Display in Kerala State, South India. New York, New York University.

BABB, Lawrence A., 1975, The Divine Hierarchy: Popular Hinduism in Central India. New York, Columbia University Press. 
BARA, Elizabeth, 2013, Dancing and the "Other": Folklorising Tribal Authenticity. Taleigaon, Goa, Goa University, M.A. thesis.

BOISSEVAIN, Jeremy, 1996, "Ritual, tourism and cultural commoditization in Malta: culture by the pound?", in Tom Selwyn (ed.), The Tourist Image: Myths and Myth Making in Tourism. Chichester, John Wiley and Sons, 105-120.

BOURDIEU, Pierre, 1972, Esquisse d'une théorie de la pratique, précédé de trois études d'ethnologie Kabyle. Geneva, Droz.

BREDA, Zélia, and Carlos COSTA, 2012, "Tourism and transformations: the case of Goa", in Artur Teodoro de Matos and João Teles e Cunha (eds.), Goa: Passado e Presente, vol. 2. Lisbon, CEPCEP, CHAM and FCT, 783-810.

CASTElO-BRANCO, Salwa El-Shawan, and Jorge Freitas BRANCO (eds.), 2003, Vozes do Povo: A Folclorização em Portugal. Oeiras, Celta.

CHANDramouli, C., 2013, Census of India 2011, Primary Census Abstract: Data Highlights India. New Delhi, Office of the Registrar General and Census Commissioner, available at $<$ http://www.censusindia.gov.in/201 lcensus/PCA/PCA_Highlights/pca_highlights_ind ia.html $>$ (last access in January 2017).

CHATTERJI, Roma, 2004, "Performative genres as boundary markers", Indian Folklife, 3 (4): 8-10.

COHEN, Anthony, 2000, "Introduction: discriminating relations - identity, boundary and authenticity”, in Anthony Cohen (ed.), Signifying Identities: Anthropological Perspectives on Boundaries and Contested Values. London and New York, Routledge, 1-14.

COHEN, Erik, 1988, "Authenticity and commoditization in tourism", Annals of Tourism Research, 15 (3): 371-386.

COUTO, Maria Aurora, 2005, Goa: A Daughter's Story. New Delhi, Penguin Books.

D'ANDREA, Anthony, 2007, Global Nomads: Techno and New Age as Transnational Countercultures in Ibiza and Goa. Oxon, Routledge.

DESSAI, Ullas Prabhu, 2006, Chandrawadicha Dhalo. Quepem, author's edition.

FERnANDES, Mozinha, 2009, Where Have All the Rand Songs Gone? A Case Study of Gawdas of Ambelim, South Goa, Department of Sociology of Goa University, Taleigaon, Goa, M.A. thesis.

FLOOD, Gavin D., 1996, An Introduction to Hinduism, Cambridge, Cambridge University Press. FUller, Christopher J., 1992, The Camphor Flame: Popular Hinduism and Society in India. Princeton and New Jersey, Princeton University Press.

GOFFMAN, Erving, 2005 [1967], Interaction Ritual: Essays in Face to Face Behavior. New Brunswick, NJ, Transaction Publishers.

GOVERnMENT OF GOA, 2005, Survey Report on the Scheduled Tribes of Goa (Gawda, Kunbi, Velip). Panaji, Directorate of Social Welfare.

GOVERNMENT OF INDIA, 2013, Statistical Profile of Scheduled Tribes in India 2013, Ministry of Tribal Affairs, Statistics Division, available at < http://tribal.nic.in/WriteReadData/userfiles/file/Statistics/StatisticalProfileofSTs2013.pdf > (last access in January 2017).

GUPTA, Pamila, 2009, "Goa Dourada, the Internal Exotic in South Asia: discourses of colonialism and tourism”, in Phukan and V. G. Rajan (eds.), Reading the Exotic: South Asia and Its Others. Cambridge, Cambridge Scholars Press.

HANDLER, Richard, 1988, Nationalism and the Politics of Culture in Quebec. Madison, The University of Wisconsin Press. 
HAYWARD, Philip, 2011, "A place in the world: globalization, music, and cultural identity in contemporary Vanuatu", in Bob W. White (ed.), Music and Globalization: Critical Encounters. Tracking Globalization. Bloomington, Indiana University Press, 52-74.

HENN, Alexander, 2003, Wacheit der Wesen: Politik, Ritual und Kunst der Akkulturation in Goa. Münster, Hamburg and London, LIT-Verlag.

HENN, Alexander, and Alito SIQUEIRA, 2010, Staying Awake for God: Introducing the Jagor [film documentary], < http://www.vimeo.com/12507263 > (accessed 03/10/2013).

HOBSBAWM, Eric, 1992 [1983], "Introduction”, in Eric Hobsbawm and Terence Ranger (eds.), The Invention of Tradition. Cambridge, Cambridge University Press.

KHEDEKAR, Vinayak, 2004, Goa Kulumi. Panaji, author's edition.

KORPELA, Mari, 2010, "A postcolonial imagination? Westerners searching for authenticity in India", Journal of Ethnic and Migration Studies, 36 (6): 1299-1315, available at < http://www.tandfonline.com/doi/abs/10.1080/13691831003687725 > (last access in January 2017).

KORPELA, Mari, 2016, "A (sub)culture of their own: children of lifestyle migrants in Goa, India", Asian and Pacific Migration Journal, 25 (4): 470-488, available at < http://journals. sagepub.com/doi/abs/10.1177/01 $17196816671959>$ (last access in January 2017).

MacCANNELL, Dean, 1973, "Staged authenticity: arrangements of social space in tourist settings", The American Journal of Sociology, 79 (3): 589-603.

MADAN, T.N., 2004, "Introduction: India's religions, plurality and pluralism", in T.N. Madan (ed.), India's Religions: Perspectives from Sociology and History. New Delhi, Oxford University Press, 1-36.

MERTON, Robert K., 1968 [1949], Sociologia: Teoria e Estrutura. São Paulo, Editora Mestre Jou.

MONTEMAYOR, J., 1970, A Sociological Study of a Village Community in Goa, Delhi, University of Delhi, PhD thesis.

NAITHANI, Sadhana, 2005, "Editorial: folklore and media”, Indian Folklife, 4 (1): 3-4.

NEWMAN, Robert S., 1984, "Goa: the transformation of an Indian region", Pacific Affairs, 57 (3): 429-449.

NHLEKISANA, Rosaleen O.B., 2011 , "Music as a catalyst for improved livelihood: the case of culture spears, a traditional music dance group in Botswana", in Rebecca Nthogo Lekoko and Ladislaus M. Semal (eds.), Cases on Developing Countries and ICT Integration: Rural Community Development. Hershey, IGI Global, 83-90.

NORONHA, L., et al., 2002, "Goa: tourism, migrations, and ecosystem transformations", Ambio, 31 (4): 295-302.

PEREIRA, Cláudia, 2003, "Os gaudde de Goa: contestação estatutária/The Gawada of Goa: a debate on status", Oriente, 6: 74-85.

PEREIRA, Cláudia, 2009, Casta, Tribo e Conversão: Os Gaudde de Goa. Lisbon, ISCTE - Instituto Universitário de Lisboa, PhD thesis in Anthropology.

PEREIRA, Cláudia, 2010, "As danças e as canções dos Gaudde católicos de Goa: o testemunho da resistência invisível ao colonialismo português através da sua tradição oral, agora folclorizada", in Rosa Maria Perez and Miguel Fialho de Brito (eds.), Revista Camões, 20. 86-103.

PEREIRA, Cláudia, 2012, "Catolicismo e hinduísmo em Goa: as canções de casamento dos Gaudde”, in Artur Teodoro de Matos and João Teles e Cunha (eds.), Goa: Passado e Presente, vol. 1. Lisbon, CEPCEP, CHAM and FCT, 353-364. 
PEREZ, Rosa Maria, 2006, "Sonhos imperiais: negociações e rupturas do colonialismo português na Índia”, in Rosa Maria Perez (ed.), Os Portugueses e o Oriente: História, Itinerários, Representações. Lisbon, Dom Quixote, 129-149.

PISTRICK, Eckehard, and Cyril ISNART, 2013, "Landscapes, soundscapes, mindscapes: introduction”, Etnográfica, 17 (3), available at < http://etnografica.revues.org/3213> (last access in January 2017).

ROSALES, Marta Vilar, 2012, "My umbilical cord to Goa: food, colonialism and transnational Goan life experiences", Food and Foodways, 20 (3-4): 233-256, available at < http://www.tandfonline.com/doi/abs/10.1080/07409710.2012.715966 > (last access in January 2017).

SAÏD, Edward W., 1996 [1978], Orientalismo: O Oriente como Invenção do Ocidente. São Paulo, Companhia das Letras.

SALDANHA, Arun, 2005, “Trance and visibility at dawn: racial dynamics in Goa's rave scene”, Social \& Cultural Geography, 6 (5): 707-721, DOI: 10.1080/14649360500258 328.

SARDO, Susana, 2011 , Guerras de Jasmim e Mogarim: Música, Identidade e Emoções em Goa. Alfragide, Texto Editora.

SILVA, José Carlos Gomes da, 1993 [1989], A Identidade Roubada. Lisbon, Gradiva.

St. JOHN, Graham, 2011 , "DJ Goa Gil: Kalifornian exile, dark yogi and dreaded anomaly”, Dancecult: Journal of Electronic Dance Music Culture, 3 (1): 97-128.

TARABOUT, Gilles, 2005, "Malabar gods, nation-building and world culture: on perceptions of the local and the global", in Jackie Assayag and J.C. Fuller (eds.), Globalizing India: Perspectives from Below. London, Anthem Press, 185-209, available at < http://gtarabout. free.fr/pdf/05-Malabar_Gods.pdf > (last access in January 2017).

TRICHUR, Raghuraman, 2007, “Tourism and nation building: (re)locating Goa in postcolonial India”, in Charles J. Borges and M. N. Pearson (eds.), Metahistory: History Questioning History. Festschrift in Honour of Teotonio R. de Souza. Lisbon, Vega, 222-231.

WAGNER, Roy, 1981, The Invention of Culture. Chicago, The University of Chicago Press.

WANG, Ning, 1999, "Rethinking authenticity in tourism experience", Annals of Tourism Research, 26 (2): 349-370.

WILSON, David, 1997, "Paradoxes of tourism in Goa", Annals of Tourism Research, 24 (1): 52-75, available at < http://dx.doi.org/10.1016/S0160-7383(96)00051-5 > (last access in January 2017).

ZHU, Yujie, 2012, "Performing heritage: rethinking authenticity in tourism", Annals of Tourism Research, 39 (3): 1495-1513, available at < http://dx.doi.org/10.1016/j.annals $.2012 .04 .003>$ (last access in January 2017). 